\title{
Differentiation of Juxtaglomerular Apparatus Cells in Developing Nephrons in BALB /c Type Mouse Embryos
}

\section{BALB/c Tipi Fare Embriyolarında Gelişen Nefronda Juxtaglomerular Aparatus Hücrelerinin Farklılaşmaları}

\author{
Beyhan Gürcü ${ }^{1 *}$, Sabire Karaçalı ${ }^{2}$ \\ ${ }^{1}$ Manisa Celal Bayar University, Faculty of Science and Letters, Department of Biology, Manisa, Turkey \\ ${ }^{2}$ Ege University, Faculty of Science, Department of Biology, Manisa, Turkey \\ e-mail: byhgurcu@gmail.com, sabire.karacali@gmail.com \\ ORCID: 0000-0001-7667-7155 \\ ORCID: 0000-0002-5793-5478 \\ *Sorumlu yazar/ Corresponding Author: Beyhan Gürcü \\ Gönderim Tarihi / Received: 18.11.2020 \\ Kabul Tarihi / Accepted: 04.08.2021 \\ DOI: $10.34087 /$ cbusbed. 827212
}

\begin{abstract}
Giriş ve Amaç: Bu çalışmada BALB/c tipi fare embriyolarında nefron gelişmesi ve bu süreç sırasında juxtaglomerular apparatus (JGA) hücrelerinin farklılaşmaları incelenmiştir. Kalın ve ince epon kesitler sırasıyla 1şık mikroskobu (IM) ve geçirimli elektron mikroskobu (TEM) ile incelenmiştir.

Gereç ve Yöntemler: Nefron gelişmesi nefrojenik kesenin virgül şekilli yapı, S-şekilli yapı, prekapiller, olgunlaşmamış glomerulus ve olgunlaşmış glomerulus safhalarını geçmesiyle tamamlanır. JGA, IM düzeyinde nefron gelişmesinin olgunlaşmış glomerulus evresinde ayırt edilir. TEM gözlemlerine göre JGA' y1 oluşturan jukstaglomerular (JG) hücreler ile macula densa (MD) hücrelerinin farklılaşmalarına dair işaretler daha erken, prekapiller evrede görülür. Prekapiller evrede JG hücreleri karakterize eden gelişmiş Golgi sahaları içinde çok sayıda elektronca az yoğun küçük kesecikler ile az sayıda elektronca yoğun iri renin granülleri görülür. Olgunlașmış glomerulus evresinde JG hücrelerdeki elektronca yoğun iri granüllerin sayısı artar. MD hücrelerinin farklılaşmalarını prekapiller evrede apikal yüzlerinde primer silia şekillenmesi işaret eder. Olgunlaşmış glomerulus evresinde MD hücrelerinin bazal ve lateral yüzlerinde derin zar katlanmaları şekillenir. Bu bölgelerde çok sayıda irileşmiş mitokondriler yer alır.

Bulgular: Renin-Angiotensin sistemin düzenlenmesinde mutlak rol oynayan JG hücreler ile MD hücreleri prekapiller evrede, nefron gelişmesi tamamlanmadan ve kan damarları şekillenmeden önce farklılaşırlar.

Sonuç: JGA hücrelerinin bu kadar erken farklılaşmaları renin-anjiotensin sisteminin hem böbrek gelişmesi ve hem de genel embriyo gelişmesindeki önemini işaret eder.
\end{abstract}

Anahtar kelimeler: Fare Embriyosu, Işık ve Geçirimli Elektron Mikroskobu, Jukstaglomerüler Hücre, Makula Densa Hücresi, Nefron Gelişmesi.

\footnotetext{
Abstract

Objective: This study examined the development of nephrons and the differentiation of juxtaglomerular apparatus (JGA) cells in BALB/c type mouse embryos. Thick and thin epon sections were investigated by light microscopy (LM) and transmission electron microscopy (TEM) respectively.

Materials and Methods: Nephron development is completed by passing through the nephrogenic vesicles in the respected stages of comma shape body, S-shape body, precapillary, immature glomerular, and mature glomerular stage. JGA is distinguished in the mature glomerular stage of nephron development at LM level. According to TEM observations, signs of differentiation of juxtaglomerular (JG) cells and macula densa (MD) cells forming JGA are seen earlier, in precapillary stage. In developed Golgi fields that characterize JG cells, large number of electron lucent small vesicles and small number of electron dense large renin granules are seen in the precapillary stage. In the mature glomerulus, the number of electron dense large granules increases in JG cells. The differentiation of MD cells is indicated by the formation of primary cilia on their apical faces in precapillary stage. Deep membrane folds are formed
} 
in the basal and lateral faces of MD cells in the mature glomerular stage. There are many numbers of large mitochondria in these regions.

Results: JG and MD cells, which play an absolute role in the regulation of the renin-angiotensin system are differentiated in precapillary stage before completion of nephron development and formation of blood vessels.

Conclusion: Such early differentiation of JGA cells suggests that the renin-angiotensin system is important both in the development of the kidney and in the total development of embryo.

Keywords: Juxtaglomerular Cell, Light and Transmission Electron Microscopy, Macula Densa Cell, Mouse Embryo, Nephron Development.

\section{Introduction}

Metanephric kidney development is a very successful model to understand the basic mechanisms that play a role in the emergence of a complex organ in the embryo. For example; how regional differences occur along body axes, how the signaling molecules secreted by intrinsic factors act, how proliferation, differentiation and apoptosis are controlled in precursor cells, how extension and branching of epithelial hollow channels are regulated and how the loosely organized mesenchyme cells change to closely attached polarized epithelial cells [1-3]. Informations about inductive signaling molecules that play a role in development and their genes are increasing [4]. The metanephric kidney develops from two mesoderm-derived structures mutually stimulating each other, ureteric bud originating from the Wolffian channel and the metanephrogenic mesenchyme cells. Metanephrogenic mesenchyme cells induce prolongation and branching of ureteric buds. The ureteric bud also effects to collect the metanephrogenic mesenchyme cells at the ends of the branches to form a cap-like structure (blastemal cap) and gradually induces the changes related to transformation from mesenchymal to epithelial cells differentiation [5]. Cells that acquire epithelial characters first form a sac called the nephrogenic vesicle. The nephron, the structural-functional unit of the metanephric kidney, develops by passing through the precapillary, immature glomerular and mature glomerular stages after comma and S-shape bodies respectively $[6,7]$. While the nephrons are developing, Juxtaglomerular Apparatus (JGA) also develops and becomes a distinguishable structure, during this process. JGA contributes the most important tasks that the kidneys perform by an active role in maintaining the water and ion homeostasis of the organism and in controlling the blood pressure. [8, 9].

JGA is a special contact zone formed from the several types of cells located around the afferent arteriole at vascular pole of the glomerulus in the nephron structure. Different types of cells located in close contact are functionally related. One of the cell types is Juxtaglomerular (JG) endocrine cells, which are located among the smooth muscle cells of the arterial wall and are releasing the renin. The second type of cells is Macula Densa (MD) sensory cells, are present in thick ascending arm of Henle loop, just before the convoluted section of distal tubule, in anatomically approaching region to afferent arteriole. Mesangial Cells (MC) spreading among these cells also form the associated third cell type $[9,10]$

The renin-angiotensin system (RAS) is an important hormonal cascade that regulates glomerular filtration and nephron fluid flow rate, salt and fluid balance, and arterial blood pressure homeostasis in the organism [1115]. JGA plays an active role in regulation of this hormonal cascade, and renal secretion is the first key step in the activation of RAS [16-20]. Renin secreting cells are necessary for the morphological integrity of the kidney and for normal kidney function to take place [21]. Endocrine and contraction tasks provide quick control of blood pressure and body fluids [22]. They are in central to perform the tasks of the JGA, and renin formation in cells is sufficient to maintain homeostasis [17]. The distribution of renin-secreting cells varies depending on the physiological state of embryonic or adult age and stimulation [23]. Renin-secreting cells bearing $\alpha$-smooth muscle actin markers resemble pericytes and myofibroblasts. Renin is stored in vesicles and granules. [24].

Renin secretion from JG cells is controlled by MD cells $[25,26]$. MD cells are specialized distal tubule cells. Each JGA has 20-30 MD cells [27]. The differentiation of rabbit MD glycocalyxes from neighboring distal cell glycocalyxes by lectin-gold marking technique [28] indicates the functional differences of these cells from distal tubule cells. MD epithelial cells are sensitive to tubular flow and salt content [29]. In accordance with anatomic localization, the MD cells identify the ionic composition of the distal tubule fluid on the one hand. On the other hand, they form and secrete paracrine chemical mediators acting on JGA effector cells (afferent arteriolar smooth muscle cells and JG cells) [18, 30, 31]. Paracrine mediators that work in this tubulo-vascular crosstalk communication are Nitric Oxide (NO) [24, 32-34] which stimulates renin secretion, Prostaglandin E2 and ATP molecules that inhibit renin secretion [30, 35]. They regulate the mechanism known as tubulo-glomerular feedback [18].

Two basic arrangements are realized with the JGA [18]. One is the stimulation of the tubuloglomerular feedback mechanism with excessive $\mathrm{NaCl}$ in the distal tubule. The other is stimulation of renin secretion with low $\mathrm{NaCl}$. $\mathrm{NaCl}$ elevation in distal tubule stimulates basolateral ATP release from MD cells. ATP stimulates internal $\mathrm{Ca}^{2+}$ release in afferent arteriolar smooth muscle cells $[35,36]$. Increased cytosolic free $\mathrm{Ca}^{2+}$ concentration in conjunction with related signal transduction pathways [10], causes contraction of afferent arteriolar smooth muscle cells [30], this contraction of afferent arterioles lead to a decrease in glomerular filtration rate [36]. Proximal tubular flow is blocked to remove excess $\mathrm{NaCl}$ by this way called tubulo-glomerular feedback. Decreased $\mathrm{NaCl}$ in the distal tubule stimulates renin 
secretion [18]. Primary Cilia extending to the lumen on the apical surfaces of the MD cells is responsible for the detection of salt, metabolites, and flow changes in the distal tubule fluid [25, 31, 36].

In general, primary cilia are nonmotile, solitary and sensory organelles with a $9+0$ axonemal microtubule organization [37-42], on the surface of the majority of differentiated mammalian cells [43-48]. They are antennas that translate extracellular specific mechanical, chemical and osmotic stimuli into intracellular biochemical responses to control cell proliferation, differentiation and movement [31, 49-54]. Primary cilia have a central role [55] in regulation of cell cycle by extracellular signals, in re-enter to cell cycle and division of differentiated cells and in the events such as autophagy, apoptosis and cell-tissue homeostasis [40, 45, 56]. It regulates signaling pathways that function in early organogenesis, for example, neurogenesis [57, 58], cardiogenesis [59], skeletogenesis [60, 61], osteogenesis [62] and odontogenesis [63].

There are receptors, ion channels and the elements of signaling pathways in particularly effecting on development such as Notch, Hedgehog, Wnt, Planar Cell Polarity, PDGF and other RTKs [37, 45-47, 56, 64-66]. Since protein synthesis is not performed in primary cilia, the proteins found in the ciliary membrane are synthesized in the cytoplasm and then transported to the membrane in a way known as intraflagellar transport [43, 47, 67, 68]. The link between basic signaling pathways and primary cilium in development has been revealed in recent years. [43, 50]. Sensitivity of cilia is related to length of the cilium [65]. Change in cilium length, damage to the primary cilium and defects in the elements of intraflagellar transport, generally cause congenital disorders or diseases, called ciliopathies $[47,55,65,69$, 70].

The presence of primary cilia in BALB/c type mouse embryonic MD cells is compatible with indications of cilia in MD cells in adult dogs [71], rabbits [36, 72] and 6-8 week old C57BL6J mouse [31]. However, there is no information on embryonic cells. In this study, differentiation of renin-secreting JG cells in the central state, and of MD cells of the chief state controlling them in the JGA formation, in the developing nephron of the $\mathrm{BALB} / \mathrm{c}$ type mouse embryos were determined. There are a number of studies to determine the origin of renin secreting cells and their role in renal vasculature. However, the information on the embryonic status and differentiation of MD cells is lacking.

\section{Materials and Methods}

BALB/c type mice were used as study material. Kidneys were sampled from $12,14,16,18$ and $20^{\text {th }}$ days old fetuses and newborns after vaginal plate (day E0) formation. The dissection of the tissues was carried out in accordance with the ethical rules of animal experimentation of Ege University.

Tissue specimens were fixed with $10 \%$ buffered neutral formalin for routine hematoxylin-eosin (H\&E) staining and Karnovsky for electron microscopic examination [73], then minimized.

For light microscopic examination; The samples were dehydrated in gradually increasing alcohols. They were clarified in xylol and embedded in paraffin. $5 \mu \mathrm{m}$ paraffin sections were stained with $\mathrm{H} \& \mathrm{E}$

For electron microscopic examination; After fixation, the samples washing with $0.1 \mathrm{M}$ cacodylate buffer $(\mathrm{pH}$ 7.4), a second fixation step was performed with buffered osmium tetroxide $\left(\mathrm{OsO}_{4}\right)$ [74] and samples were clarified with toluol after dehydration by passing through ethanol gradients series $(25 \%, 50,75,90,100)$ and embedded in resin, Epon 812 (Serva). Thick sections of $1 \mu \mathrm{m}$ thickness was stained with $1 \%$ borax toluidine blue and used for light microscopic investigation. Thin sections were stained with uranyl acetate-lead citrate [74] and examined by Transmission-Electron microscope (Jeol 100C).

\section{Results and Discussion}

\subsection{Light Microscopic Findings}

Development of nephron in BALB/c type mice begins with the formation of nephrogenic vesicles by acquiring polarized and firmly adherent epithelial cell characters of loosely structured metanephrogenic mesenchyme cells piled up at the ureteric bud tips (Figure 1A). The development is completed by passing of the nephrogenic vesicle through the stages of in comma-shaped body (Figure 1B), S-shaped body (Figure 1C), precapillary (Figure $1 \mathrm{D}, \mathrm{E}$ ), the immature glomerular (Figure 1F) and the mature glomerular (Figure $1 \mathrm{G}$ ), respectively.

Cell group that will form glomerulus and tubule regions approach each other on the 12th day of embryonic development in the S-shape body stage (Figure 1C). At the beginning of this stage, since there are few mesangial cells between them, the cell groups that will form the tubules and the glomerulus are close to each other (Figure 1C). In the precapillary stage of the development, the two layers of the Bowman capsule become distinct (Figure 1D). Between the Bowman capsule and the tubular cells facing it, more mesangial cells are inserted as if they were flowing (Figure 1E).

It is known that the cells, migrating from non-glomerular mesangial cells to this region, form blood vessels and differentiate also into secretory cells located around them $[75,76]$.

Nephron development in BALB/c type mice reaches to the immature glomerular stage at the 14th day of embryonic development. From the 18th day of development, the mature glomerular stage is commonly seen in the medulla of the kidney (Fig. $1 \mathrm{G}, \mathrm{H}$ ). In the periphery of the kidney, induction for new nephron development continues (Figure $1 \mathrm{H}, \mathrm{I}$ ).

\subsection{Transmission Electron Microscopic Findings}

JGA is distinguished in the mature glomerular stage (Figure 1G) at the level of light microscopy, as a close contact zone of several differentiated cells. TEM observations indicate that cell types participating in the JGA structure, begin to differentiate at an earlier stage of nephron development. 

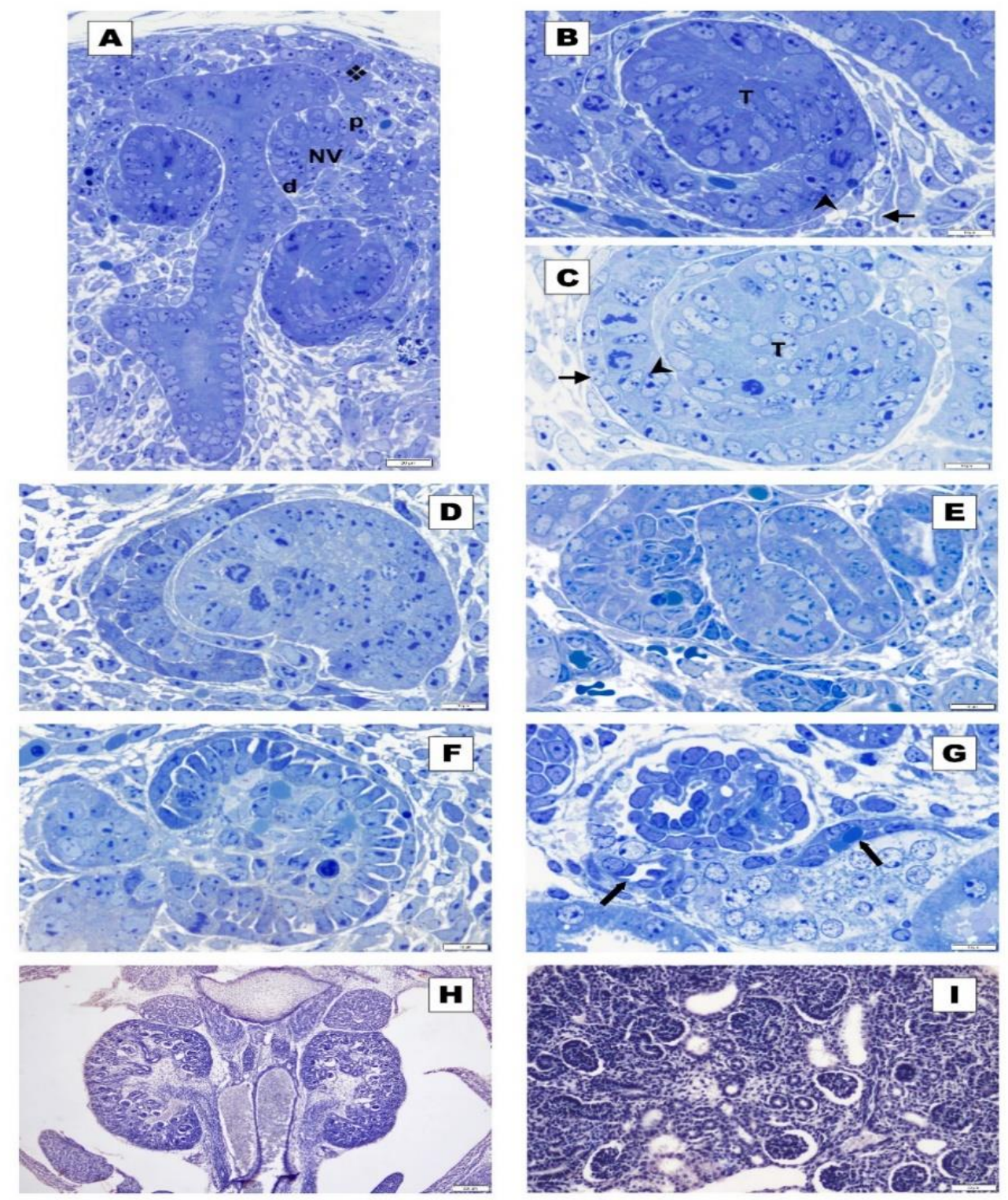

Figure 1. Nephron development in BALB/c type mouse embryos. Nephron development begins with formation of a sac, namely the nephrogenic vesicle $(\mathrm{NV})$ which is formed from the cells acquired epithelial characteristics and separated from blastemal cap. A blastemal cap $(*)$ and a NV together with a proximal (p) and distal (d) portions appear in A. Occurrence of a cleft in distal part of the NV causes the formation of a comma like structure (B). The hook-shaped tip of this cleft is composed of two cell layers, the parietal layer $(\rightarrow)$ of the Bowman capsule, and the visceral epithelium ( $\mathbf{A}$ ) where podocytes develop. Proximal part of this structure forms tubules (T) in B and C. The nephron structure that develops by rapid mitosis and elongation towards the back passes through the S-shaped body stage (C). With intense mitotic activity, the tubules extend by making mandatory curls when the site is narrow. The development of nephron is completed by passing through the stages of the precapillary (D, E), immature glomerular $(\mathrm{F})$ and mature glomerular $(\mathrm{G}) \boldsymbol{\rightarrow}$ : Vascular pole at the mature glomerular stage. Embryonic stimulation continues under the capsule when the mature glomeruli, the first to form, are located near the medulla of the kidney in $18^{\text {th }}$ day of the development (Figure H, I). (1 $\mu \mathrm{m}$ Epon section, toluidin blue (A-G). $5 \mu \mathrm{m}$ Paraffine section hematoxylin eosin (H, I), Scale, A:20, B-G:10, H:200, I:50 $\mu \mathrm{m})$.

The first morphological signs of cell differentiation are seen in S-shaped body stage (Figure 1C).

Visceral cells of Bowman's capsule, tubule cells and mesangial cells inserted between them, all are located close to each other and directly faced by plasma membrane and surface covers in the S-shaped body stage (Figure 2). They are characteristic embryonic cells with abundant free polysomes in their cytoplasm. According to electron density mesangial cell cytoplasm is less dense than other cells. However, as signs of differentiation in the podocyte cells in the Bowman capsule visceral layer, occurrence of large intercellular spaces created by the deep foldings of the plasma membrane and the initiation of formation of primer podocyte feet attached to the basal plate can be shown (Figure 2).

Initial signs of differentiation of JGA-forming cells are observed in the precapillary stage (Figure 3). Cells located between the basal sides of tubule cells with Bowman's capsule visceral cells, begin to differentiate into juxtaglomerular (JG) endocrine cells releasing renin. Numerous developed Golgi fields are seen in the cells. Golgi fields have abundant clear vesicles. Similar clear vesicles are defined as prorenin vesicles containing inactive renin [19]. 


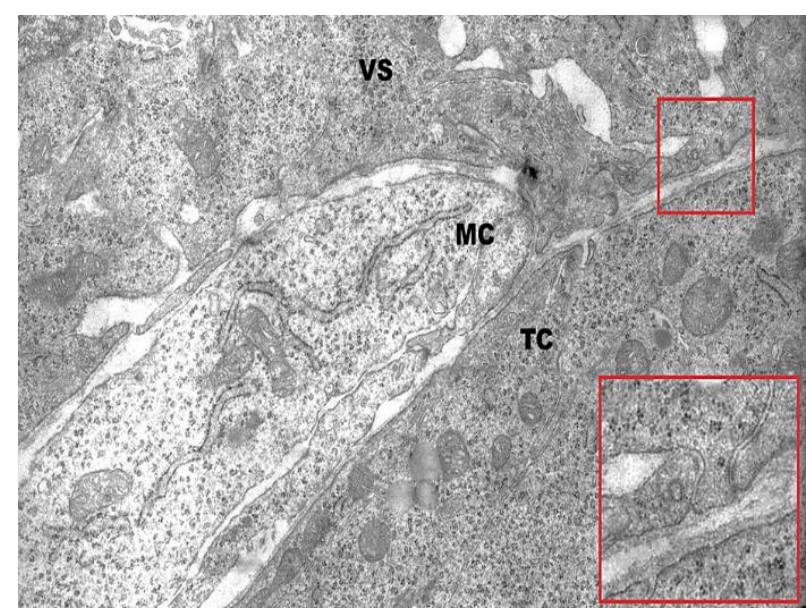

Figure 2. The S-shape body stage. Bowman's capsule visceral cell (VS), tubule cell (TC) and mesangial cell (MC) inserted between them. All are located close to each other and directly faced by plasma membrane surface covers. Initiation of a primer podocyte foot in red small square and an enlarged image in red big square. (Uranyl acetate and lead citrate, X 21168).

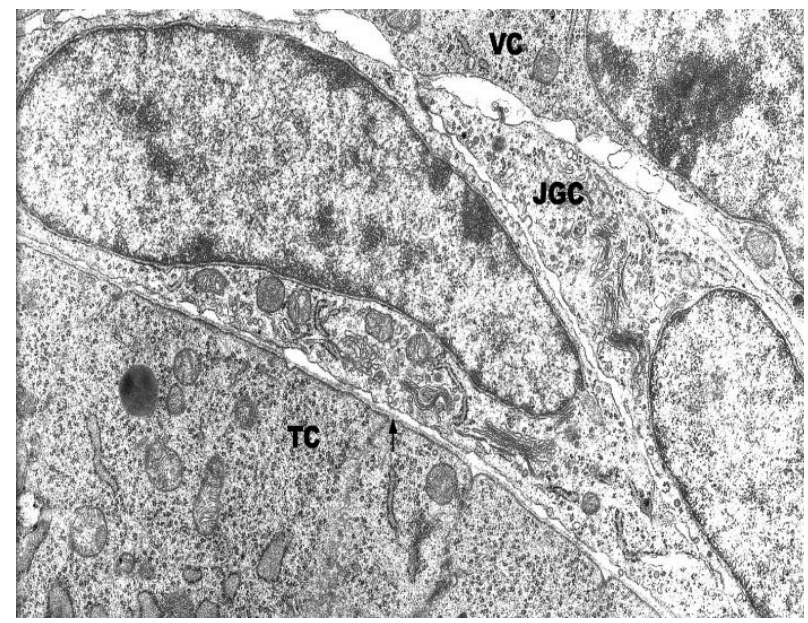

Figure 3. The precapillary stage. Tubule cells (TC), visceral cells (VC) and the cells in the differentiation process for JG cells (JGC). Basal layer $(\rightarrow)$ (Uranyl acetate-lead citrate, X 22825).

There is no noticeable additionally signs for differentiation in the basal membranes of the visceral layer and tubule cells facing with the mesangial cells. However, enlarged granular endoplasmic reticulum vesicles in tubule cells are more abundant than found in the cells of S-shaped body stage. On the lumenal side of some tubule cells, there are the signs that the cells in this region differentiated to the MD cells. Some cells have a characteristic cilium structure with basal body and sister centriole structure underlying the plasma membranes (Figure 4).

The development of the cilia on the apical surfaces indicates that these tubule cells are differentiated to the sensor MD cells in the precapillary stage.

Two polar zones of Bowman's capsule, namely vascular and urinary zone, are distinguished in mature glomerular stage (Figure 1G). At the electron microscopic level, renin-secretory granules become larger in JG cells (Figure 5).

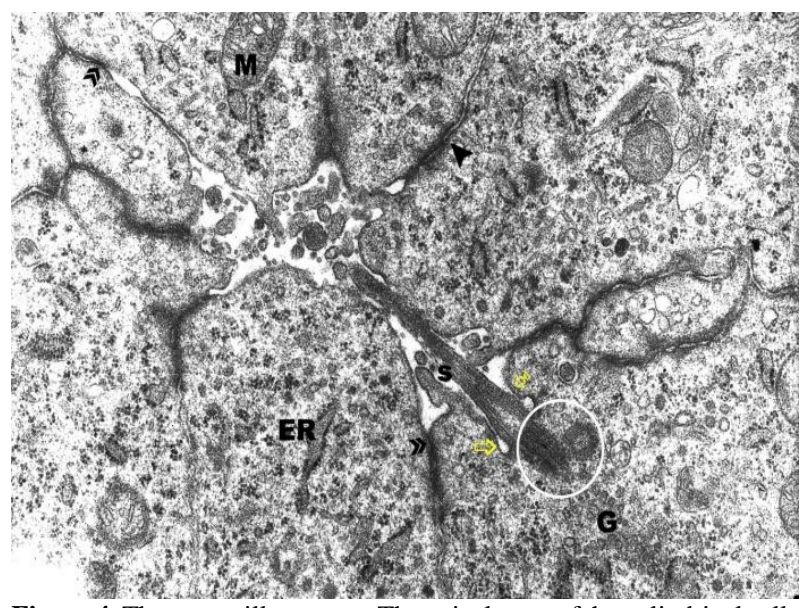

Figure 4. The precapillary stage. The apical parts of the cylindrical cells in occurrence region of the macula densa. Golgi area (G), granular endoplasmic reticulum (ER), mitochondrium (M), desmosome structures $(\triangleright)$, tight junction ( >) regions, cilium (s) structure, basal body and sister centriole in white circle, ciliary pocked $(\Rightarrow)$, cell membrane (令) (Uranyl acetate-lead citrate, X 20750).

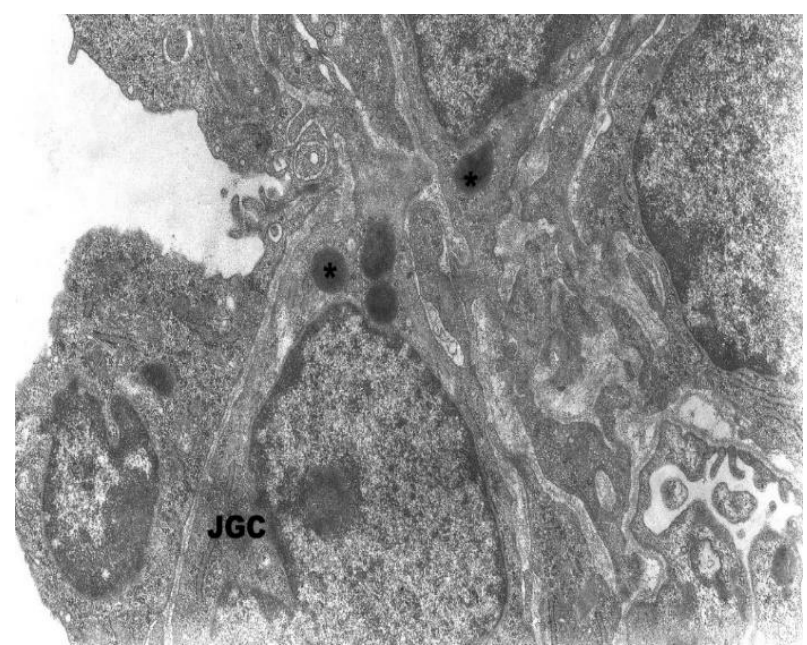

Figure 5. The mature glomerular stage. Large and electron dense reninlike secretory granules (*) in Juxtaglomerular cell (JGC), (Uranyl acetate-lead citrate, $\mathrm{X}$ 20750)

Apart from the afferent arteriolar, there are many of JG cells with extensions. Some of them resemble smooth muscle cells with myofibril bundles present in their cytoplasm MD cells are rich in organelles. The number and size of mitochondria have increased. Numerous membrane folds are seen on the basal and lateral sides of the cells. Mitochondria are also concentrated in these regions (Figure 6). The characteristic structural features of JGA cells, which are started to be distinguished in precapillary stage and completed in the mature glomerular stage, are summarized in figure 7. 


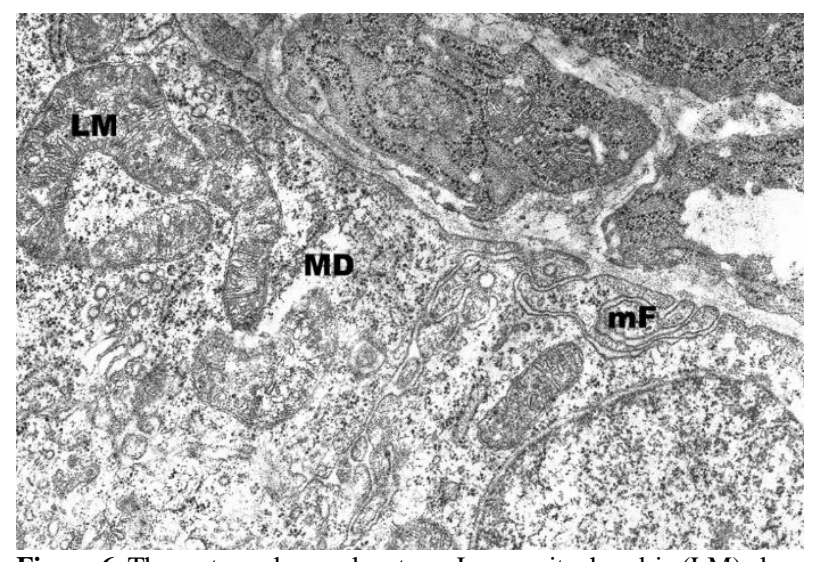

Figure 6. The mature glomerular stage. Large mitochondria (LM) close to the membrane folds $(\mathrm{mF})$ on the basal side of MD cell. (Uranyl acetate-lead citrate, X 20750).

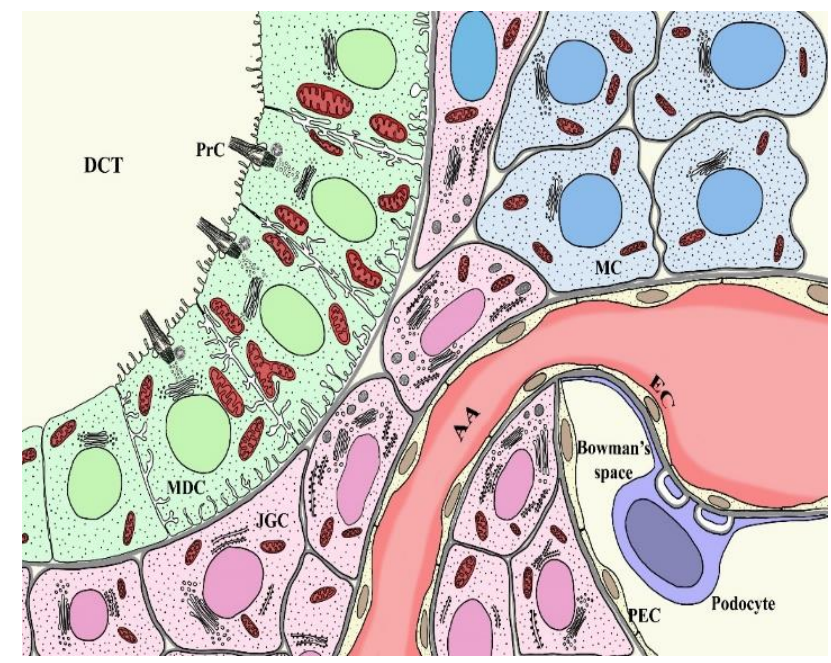

Figure 7. JGA cells. Schematic features of juxtaglomerular cells (JGCs) around the afferent arteriol (AA), macula densa cells (MDCs) in close contact with JGC and mesangial cells (MCs) among them. PrC: Primary Cilium, EC: Endothelial Cell, PEC: Parietal Cell, DCT: Distal Convoluted Tubule.

\subsection{Discussion}

Development of metanephric kidney in mouse embryo begins by stimulation ureteric bud formation from the Wolffian ducts by the signals originating from metanephrogenic blastema in the caudal part of the intermediate mesoderm. It has been reported that this stimulation started at the earliest 9th (E9) day [6] or 9.5th (E9.5) day [77] prevalently after the 10th day (E10.5) [3, $4,7,78]$. In present study, a blastemal cap occurring from metanephrogenic mesenchymal cells was formed on the $11^{\text {th }}$ (E11) day of the development. After this initial stimulation, metanephric kidney development is directed by both of ureteric bud and the metanephrogenic cell population adjacent to the ureteric bud [79]. All the stage of nephrogenesis in BALB/c type mice are compatible with the notifications in other mice $[6,80]$. However, the completion times of the stages were appeared slightly later manner. For example, the occurrence of the first mature glomerulus was mentioned after $14^{\text {th }}$ day of the development [6], whereas it was observed in $18^{\text {th }}$ day of the development, in BALB/c type mice. New branches produced successively from ureteric buds by the inductions of metanephrogenic mesenchymes intercalate into the metanephrogenic mesenchymes. A blastema cap from metanephrogenic mesenchymal cells is formed on the $11^{\text {th }}$ (E11) day of embryonic development and later a nephrogenic vesicle occurs from epithelial cells originating from metanephrogenic mesenchyme. All regions of the nephron structure develop from this nephrogenic vesicle, by passing all the steps of nephrogenesis. The first mature glomerulus is produced after $14^{\text {th }}$ day of embryonic development (E14.5) [6]. Stages of nephrogenesis in BALB/c type mice are compatible with the notifications in other mice $[6,80]$ summarized above. However, in this study, glomerulus was observed slightly later, on $18^{\text {th }}$ day than the others.

One of the cells that started to differentiate first from the embryonic cells in the nephron structure, is podocyte cells. The observations of distinguishable of visceral and parietal cells at LM level (Figure 1C), and large intercellular spaces together with beginning of podocyte feet formation at TEM level (Figure 2) are consistent with the finding that $\mathrm{R}$ cadherin (which plays an important role in the early stages of glomerulogenesis) detection on mouse primer podocyte feet in the S-shaped phase by an immuno-gold [81] staining method. In addition, the presence of D1 type cyclin (which is responsible for the regulation of proliferation and differentiation) in the S- and comma-like body stages, while the presence of cyclin D3 [82] at the following stages indicates that podocytes differentiate early in development of nephrons. In the following precapillary stage, the cells forming the JGA are differentiated.

JG cell progenitors differentiate from the cell population containing the Fox D1 transcription factor among undifferentiated metanephrogenic mesenchyme cells [83-86] before vascularization in embryonic kidney interstium [87]. Renin expressing JG cells are also progenitor cells for nonrenin-forming cells, such as smooth muscle, pericyte, mesangial, epithelial, extrarenal and podocytes [20, 21, 8890]. Renin-forming cells are likely to play a role in the development of kidney vessels [16, 20, 83, 85-87] by synthesizing other factors [83]. The differentiation of reninsecreting cells in the JGA in the precapillary stage of nephron formation in the 14-day embryo with TEM in BALB/c type mice overlaps with the detection of renin mRNA in mouse embryonic kidney before 14.5 days of arterial development [91]. In this study, the electron lucent small vesicles in precapillary stage and the electron dense granules increased in size and number in the mature glomerular stage are similar to the inactive prorenin and active renin containing granules, respectively, as previously identified in mouse JG cells [19]. Non-active prorenin is glycosylated in the Golgi vesicle during the course of the maturation. During the activation of renin granules, the prosegments are cutted and removed, and small granules are combined [19]. Mature renin granules have different internal electron densities [92]. It is reported that $75 \%$ of the renin synthesized in JG cells is prorenin, $25 \%$ of them form electron dense secretory granules [93] and mature granules are secreted by exocytosis $[19,23]$.

$\mathrm{MD}$, which are the JGA sensory cells, plays an important role in the control of renin secretion $[18,31,35,36]$. 
Regulation of renin secretion [18, 24, 35] and tubuloglomerular feedback formation $[10,18,31,36]$ are realized by paracrine effects [25] using NO [32], prostaglandin E2 and ATP $[30,35]$ which are formed by MD cells. For this purpose, primary cilia are responsible $[31,36]$ for the detection of the changes in salt, metabolites, and flow in the distal tubule fluid of MD [25, $30,31,36]$

The first record of the presence of single or multiple cilium together with basal body and centriole, which has $9+2$ tubule structure in MD cells, belongs to the dog kidney MD [71]. Subsequently, it was reported that rabbit kidney MD cells also carry cilia [72]. The presence of primary cilia with 5-8 $\mu \mathrm{m}$ length in the apical membranes of each MD cell was showed by immunofluorescence marking of $\alpha$ tubulin which is a ubiquitous component of primary cilia in 6-8 week-old C57BL6J mice, and was reported to act as a current sensor [31]. In 8-12 week-old C57BL/6 mice, nitric oxide (NO) formation was measured with fluorescence dye [27] in mice specifically knock-out of primary cilia in MD and thick ascending limb. Dominant isoform of NO in MD cells is induced by NOS1 (Neuronal nitric oxide synthase 1). Knocked out mice showed a rapid tubuloglomerular feedback response in both in vivo and in vitro conditions together with marked reduction in $\mathrm{NO}$ formation.

It has been reported that primary cilia present in New Zealand white rabbit MD cells act as a current sensor to activate NOS [36] to accelerate NO formation that inhibits tubuloglomerular feedback response. In this study, it is seen that in BALB/c type mice, the MD cells carry the primary cilium with a characteristic basal body (mother centriole), the ciliary pockets and a sister centriole (Figure 4). Since the primary cilium supported by the basal body is an organelle in undividing cells [49] and in differentiated cells staying in the $G_{1} / G_{0}$ phase of the cell cycle $[94,95]$, it is acceptable that the MD cells differentiated in precapillary stage of the developing nephron. These early differentiations of MD cells are related to their important role in the chief position in the JGA, which plays an active role in the RAS cascade that regulates fluid and electrolyte homeostasis in the organism.

The primary cilia detect changes in the MD lumen and transmits them to the cells to perform their assigned tasks. Primary cilia in the development of mammalian kidney are seen in no more dividing cells of the ureteric buds and the renal vesicle, in early stages of the nephron development. Following in comma-shaped body and S-shaped body stages, the primary cilia appear in the cells of collecting ducts. In mature nephron, they are commonly found in the cells of nephron tubules and collecting ducts [96]. The primary cilia in the kidney feels a flow of urine, controls cellular responses, and is necessary for the protection of the epithelial sheaths of the tubules [97]. They play a critical role in kidney pathophysiology. Deficiency of primary cilia initiates to get mesenchymal characterization of epithelial cells [98].

The presence of basal bodies and centrioles in basal part of cilia is a special feature of cells [39]. The primary ciliamediated signaling plays a role in various cellular events such as proliferation, differentiation, cytoskeleton organization, movement, cell cycle regulation, apoptosis, and autophagy in epithelial cells $[56,69,96,99,100]$. The control of cell cycle and movement are critical events for development and performances of the tasks of the tissues [50]. If primary cilia-bearing differentiated cells decide to continue the cell cycle, the structure of primary cilia begins to disintegrate [94]. Re-entry into the cell cycle of the cells is the insurance of repair events in the kidney tubule cells. [97]. The evens for proliferation and cell differentiation are precisely controlled during repair. Extensive efforts are being made to explain the mechanisms of cell cycle-related formation and disruption of the primary cilia to regenerate damaged cells [49] and to control tissue repair [101]

\section{Conclusion}

JG and MD cells were differentiated in precapillary stage before completion of nephron development and formation blood vessels in developing embryo.

The differentiations of JG and MD cells were characterized by the formation of renin granules and primary cilia, respectively. Renin-angiotensin system a largely widespreading in embryo and mature organism is responsible for the continue of homeostasis. Since all cell types bearing primary cilia have a repairing and restoration capacities, this potential of MD cells is very valuable and creative for the efforts to improve the disorders in the reninangiotensin system.

\section{Acknowledgement and Disclosures}

We would like to express our thanks to Fatih ÇÖLLÜ, MSc, for the preparation of the illustration.

\section{References}

1. Dressler, G.R, Advances in early kidney specification, development and patterning, Development, 2009, 136(23), $3863-$ 74 .

2. Krause, M, Rak-Raszewska, A, Pietila, I, Quaggin, S.E, Vainio, S, Signaling during kidney development, Cells, 2015, 4(2), 112-32.

3. Vainio, S, Lin, Y, Coordinating early kidney development: lessons from gene targeting, Nature Reviews Genetics, 2002, 3(7), 533-43.

4. Costantini, F, Kopan, R, Patterning a complex organ: branching morphogenesis and nephron segmentation in kidney development, Developmental Cell, 2010, 18(5), 698-712.

5. Gilbert, S.F, Barresi, M.J.F, Developmental Biology, 11th Edition, American Journal of Medical Genetics Part A, 2017, 173(5), 14301430.

6. Reidy, K.J, Rosenblum, N.D, Cell and molecular biology of kidney development, Seminars in nephrology, 2009, 29(4), 321-37.

7. Self, M, Lagutin, O.V, Bowling, B, Hendrix, J, Cai, Y, Dressler G.R, Oliver G, Six2 is required for suppression of nephrogenesis and progenitor renewal in the developing kidney, The EMBO journal, 2006, 25(21), 5214-28.

8. Hanner, F, von Maltzahn, J, Maxeiner, S, Toma, I, Sipos, A, Kruger, O, Willecke, K, Peti-Peterdi, J, Connexin45 is expressed in the juxtaglomerular apparatus and is involved in the regulation of renin secretion and blood pressure, American journal of physiology. Regulatory, integrative and comparative physiology, 2008, 295(2), R371-80.

9. Yao, J, Oite, T, Kitamura, M, Gap junctional intercellular communication in the juxtaglomerular apparatus, American Journal of Physiology - Renal Physiology, 2009, 296(5), F939F946.

10. Carlstrom, M, Wilcox, C.S, Arendshorst, W.J, Renal autoregulation in health and disease, Physiology Review, 2015, 95(2), 405-511.

11. Castellanos Rivera, R.M, Monteagudo, M.C, Pentz, E.S, Glenn, S.T, Gross, K.W, Carretero, O, Sequeira-Lopez M.L., Gomez 
R.A., Transcriptional regulator RBP-J regulates the number and plasticity of renin cells, Physiological Genomics, 2011, 43(17), 1021-8.

12. Fyhrquist, F, Saijonmaa, O, Renin-angiotensin system revisited, Journal of internal medicine, 2008, 264(3), 224-36.

13. Laragh, J.H, Sealey, J.E, The plasma renin test reveals the contribution of body sodium-volume content (V) and reninangiotensin (R) vasoconstriction to long-term blood pressure, American journal of hypertension, 2011, 24(11), 1164-80.

14. Li, X.C, Zhu, D, Zheng, X, Zhang, J, Zhuo, J.L, Intratubular and intracellular renin-angiotensin system in the kidney: a unifying perspective in blood pressure control, Clinical science (London, England : 1979), 2018, 132(13), 1383-1401.

15. Schweda, F, Salt feedback on the renin-angiotensin-aldosterone system, Pflugers Archiv : European journal of physiology, 2015, 467(3), 565-76.

16. Freeburg, P.B, Abrahamson, D.R, Dissecting the JGA: new functions for JG cells?, Regulatory, integrative and comparative physiology, 2004, 286(3), R449-50.

17. Martini, A.G, Danser A.H.J, Juxtaglomerular Cell Phenotypic Plasticity, High blood pressure \& cardiovascular prevention: the official journal of the Italian Society of Hypertension, 2017.

18. Peti-Peterdi, J, Harris R.C, Macula densa sensing and signaling mechanisms of renin release, Journal of the American Society of Nephrology : JASN, 2010, 21(7), 1093-6.

19. Schweda, F, Friis, U, Wagner, C, Skott, O, Kurtz, A, Renin release, Physiology (Bethesda), 2007, 22, 310-9.

20. Sequeira Lopez, M.L, Pentz, E.S, Nomasa, T, Smithies, O, Gomez R.A, Renin cells are precursors for multiple cell types that switch to the renin phenotype when homeostasis is threatened, Developmental cell, 2004, 6(5), 719-28.

21. Pentz, E.S, Moyano, M.A, Thornhill, B.A, Sequeira Lopez, M.L, Gomez, R.A, Ablation of renin-expressing juxtaglomerular cells results in a distinct kidney phenotype, American journal of physiology. Regulatory, integrative and comparative physiology, 2004, 286(3), R474-83

22. Brunskill, E.W, Georgas, K, Rumballe, B, Little, M.H, Potter, S.S, Defining the molecular character of the developing and adult kidney podocyte, PLoS One, 2011, 6(9), e24640.

23. Friis, U.G, Madsen, K, Stubbe, J, Hansen, P.B, Svenningsen, P, Bie, $\mathrm{P}$, et al., Regulation of renin secretion by renal juxtaglomerular cells, Pflugers Archive, 2013, 465(1), 25-37.

24. Kurtz, A, Renin release: sites, mechanisms, and control, Annиal Review of Physiology, 2011, 73, 377-99.

25. Peti-Peterdi, J, Newly Stemming Functions of Macula DensaDerived Prostanoids, Hypertension, 2015, 65(5), 987-988.

26. Vargas, S.L, Toma, I, Kang, J.J, Meer, E.J, Peti-Peterdi, J, Activation of the succinate receptor GPR91 in macula densa cells causes renin release, Journal of the American Society of Nephrology : JASN, 2009, 20(5), 1002-11.

27. Song, J, Wang, L, Fan, F, Wei, J, Zhang, J, Lu Y, Fu Y, Wang S, Juncos L.A, Liu R, Role of the Primary Cilia on the Macula Densa and Thick Ascending Limbs in Regulation of Sodium Excretion and Hemodynamics, Hypertension, 2017, 70(2), 324-333.

28. Rielle, J.C, Brown, D, Orci, L, Differences in glycocalyx composition between cells of the cortical thick ascending limb of Henle and the macula densa revealed by lectin-gold cytochemistry, The Anatomical record, 1987, 218(3), 243-8.

29. Komlosi, P, Bell, P.D, Zhang, Z.R, Tubuloglomerular feedback mechanisms in nephron segments beyond the macula densa, Current opinion in nephrology and hypertension, 2009, 18(1), $57-$ 62

30. Bell, P.D, Komlosi, P, Zhang, Z.-R, ATP as a mediator of macula densa cell signalling, Purinergic Signalling, 2009, 5(4), 461-471.

31. Sipos, A, Vargas S, Peti-Peterdi J, Direct demonstration of tubular fluid flow sensing by macula densa cells, American Journal of Physiology - Renal Physiology, 2010, 299(5), F1087-F1093.

32. Ibarra, M.E, Albertoni Borghese, M.F, Majowicz, M.P, Ortiz M.C, Loidl F, Rey-Funes, M, Di Ciano, L.A, Ibarra, F.R, Concerted regulation of renal plasma flow and glomerular filtration rate by renal dopamine and NOS I in rats on high salt intake, Physiological Reports, 2017, 5(6).

33. Persson, A.E, Bachmann S, Constitutive nitric oxide synthesis in the kidney--functions at the juxtaglomerular apparatus, Actc physiologica Scandinavica, 2000, 169(4), 317-324.
34. Tojo, A, Gross, S.S, Zhang, L, Tisher, C.C, Schmidt, H.H, Wilcox, C.S, Madsen, K.M, Immunocytochemical localization of distinct isoforms of nitric oxide synthase in the juxtaglomerular apparatus of normal rat kidney, Journal of the American Society of Nephrology, 1994, 4(7), 1438-47

35. Persson, A.E.G, Ollerstam, A, Liu, R, Brown, R, Mechanisms for macula densa cell release of renin, Acta Physiologica Scandinavica, 2004, 181(4), 471-474

36. Wang, L, Shen, C, Liu, H, Wang, S, Chen, X, Roman, R.J, Juncos, L.A, Lu, Y, Wei, J, Zhang, J, Yip, K.P, Liu, R, Shear stress blunts tubuloglomerular feedback partially mediated by primary cilia and nitric oxide at the macula densa, American journal of physiology. Regulatory, integrative and comparative physiology, 2015, 309(7), R757-66

37. Abou Alaiwi, W.A, Lo, S.T, Nauli, S.M, Primary cilia: highly sophisticated biological sensors, Sensors (Basel), 2009, 9(9), 700320.

38. Christensen, S.T, Pedersen, L.B, Schneider, L, Satir, P, Sensory cilia and integration of signal transduction in human health and disease, Traffic, 2007, 8(2), 97-109.

39. Gerdes, J.M, Davis, E.E, Katsanis, N, The vertebrate primary cilium in development, homeostasis, and disease, Cell, 2009, 137(1), 3245.

40. Ke, Y.N, Yang, W.X, Primary cilium: an elaborate structure that blocks cell division?, Gene, 2014, 547(2), 175-85.

41. Prasad, R.M, Jin, X, Nauli, S.M, Sensing a sensor: identifying the mechanosensory function of primary cilia, Biosensors (Basel), 2014, 4(1), 47-62.

42. Verschuren, E.H.J, Castenmiller, C, Peters, D.J.M, Arjona, F.J, Bindels, R.J.M, Hoenderop, J.G.J, Sensing of tubular flow and renal electrolyte transport, Nature reviews. Nephrology, 2020, 16(6), 337-351.

43. Barker, A.R, Thomas, R, Dawe, H.R, Meckel-Gruber syndrome and the role of primary cilia in kidney, skeleton, and central nervous system development, Organogenesis, 2014, 10(1), 96-107.

44. Pazour, G.J, Witman, G.B, The vertebrate primary cilium is sensory organelle, Current opinion in cell biology, 2003, 15(1), 105-10.

45. Satir, P, Pedersen, L.B, Christensen, S.T, The primary cilium at a glance, Journal of cell science, 2010, 123(Pt 4), 499-503.

46. Veland, I.R, Awan, A, Pedersen, L.B, Yoder, B.K, Christensen, S.T, Primary cilia and signaling pathways in mammalian development, health and disease, Nephron Physiology, 2009, 111(3), 39-53.

47. Venkatesh, D, Primary cilia, Journal of oral and maxillofacial pathology : JOMFP, 2017, 21(1), 8-10.

48. Hossain, D, Tsang, W.Y, The role of ubiquitination in the regulation of primary cilia assembly and disassembly, Seminars in cell \& developmental biology, 2019, 93, 145-152.

49. Carroll, B, Korolchuk V.I, Nutrient sensing, growth and senescence, The FEBS journal, 2018, 285(11), 1948-1958.

50. Christensen, S.T, Pedersen S.F, Satir P, Veland I.R, Schneider L, The primary cilium coordinates signaling pathways in cell cycle control and migration during development and tissue repair, Current topics in developmental biology, 2008, 85, 261-301.

51. Goetz, S.C, Anderson, K.V, The primary cilium: a signalling centre during vertebrate development, Nature reviews, Genetics, 2010 , 11(5), 331-44

52. Malicki, J.J, Johnson, C.A, The Cilium: Cellular Antenna and Central Processing Unit, Trends in cell biology, 2017, 27(2), 126140 .

53. Muhammad, H, Rais, Y, Miosge, N, Ornan, E.M, The primary cilium as a dual sensor of mechanochemical signals in chondrocytes, Cellular and molecular life sciences : CMLS, 2012 69(13), 2101-7.

54. Nauli, S.M, Jin, X, AbouAlaiwi, W.A, El-Jouni, W, Su, X, Zhou J, Non-motile primary cilia as fluid shear stress mechanosensors, Methods in enzymology, 2013, 525, 1-20.

55. Cortes, C.R, Metzis, V, Wicking, C, Unmasking the ciliopathies: craniofacial defects and the primary cilium, Wiley interdisciplinary reviews. Developmental biology, 2015, 4(6), 637-53.

56. Pala, R, Alomari, N, Nauli, S.M, Primary Cilium-Dependent Signaling Mechanisms, International journal of molecular sciences, 2017, 18(11).

57. Foerster, P, Daclin, M, Asm, S, Faucourt, M, Boletta, A, Genovesio, $\mathrm{A}$, et al., mTORC1 signaling and primary cilia are required for 
brain ventricle morphogenesis, Development, 2017, 144(2), 201210 .

58. Kirschen, G.W, Xiong, Q, Primary cilia as a novel horizon between neuron and environment, Neural regeneration research, 2017, 12(8), 1225-1230.

59. Diguet, N, Le Garrec, J.F, Lucchesi, T, Meilhac, S.M, Imaging and analyzing primary cilia in cardiac cells, Methods in cell biology, 2015, 127, 55-73.

60. Noda, K, Kitami, M, Kitami, K, Kaku, M, Komatsu, Y, Canonical and noncanonical intraflagellar transport regulates craniofacia skeletal development, Proceedings of the National Academy of Sciences of the United States of America, 2016, 113(19), E258997.

61. Yuan, X, Yang, S, Primary Cilia and Intraflagellar Transport Proteins in Bone and Cartilage, Journal of dental research, 2016, 95(12), 1341-1349.

62. Cai, S, Bodle, J.C, Mathieu, P.S, Amos, A, Hamouda, M, Bernacki, $\mathrm{S}$, et al., Primary cilia are sensors of electrical field stimulation to induce osteogenesis of human adipose-derived stem cells, FASEB journal : official publication of the Federation of American Societies for Experimental Biology, 2017, 31(1), 346-355.

63. Hampl, M, Cela, P, Szabo-Rogers, H.L, Kunova Bosakova, M, Dosedelova, H, Krejci, P, Buchtova, M, Role of Primary Cilia in Odontogenesis, Journal of dental research, 2017, 96(9), 965-974.

64. Satir, P, CILIA: before and after, Cilia, 2017, 6, 1 .

65. Sherpa, R.T, Atkinson, K.F, Ferreira, V.P, Nauli, S.M, Rapamycin increases length and mechanosensory function of primary cilia in renal epithelial and vascular endothelial cells, International education and research journal, 2016, 2(12), 91-97.

66. Wheway, G, Nazlamova, L, Hancock, J.T, Signaling through the Primary Cilium, Frontiers in cell and developmental biology, 2018, 6, 8 .

67. Davis, E.E, Brueckner M., Katsanis N., The emerging complexity of the vertebrate cilium: new functional roles for an ancient organelle, Developmental cell, 2006, 11(1), 9-19.

68. Rosenbaum, J.L, Witman, G.B, Intraflagellar transport, Nature reviews. Molecular cell biology, 2002, 3(11), 813-25.

69. Avalos, Y, Pena-Oyarzun, D, Budini, M, Morselli, E, Criollo, A, New Roles of the Primary Cilium in Autophagy, BioMed research international, 2017, 2017, 4367019.

70. Ko, J.Y, Functional Study of the Primary Cilia in ADPKD, Advances in experimental medicine and biology, 2016, 933, 45-57.

71. Sottiurai, V, Malvin R.L, The demonstration of cilia in canine macula densa cells, American Journal of Anatomy, 1972, 135(2), 281-6.

72. Norgaard, T, The ultrastructure of the macula densa during altered sodium intake. A morphometric study of the macula densa in the rabbit nephron, Acta pathologica, microbiologica, et immunologica Scandinavica. Section A, Pathology, 1982, 90(1), 67-73.

73. Karnovsky, M, A Formaldehyde-Glutaraldehyde Fixative of High Osmolality for Use in Electron Microscopy, Journal of Cell Biology, 1964, 27, 137-8A.

74. Reynolds, E.S, The use of lead citrate at high $\mathrm{pH}$ as an electronopaque stain in electron microscopy, Journal of Cell Biology, 1963, 17, 208-12.

75. Quaggin, S.E, Kreidberg, J.A, Development of the renal glomerulus: good neighbors and good fences, Development, 2008, 135(4), 609-20.

76. Vaughan, M.R, Quaggin, S.E, How do mesangial and endothelial cells form the glomerular tuft?, Journal of the American Society of Nephrology : JASN, 2008, 19(1), 24-33.

77. Lyons, K.M, Hogan, B.L, Robertson, E.J, Colocalization of BMP 7 and BMP 2 RNAs suggests that these factors cooperatively mediate tissue interactions during murine development, Mechanisms of development, 1995, 50(1), 71-83.

78. Huang, J, Arsenault, M, Kann, M, Lopez-Mendez, C, Saleh, M, Wadowska, D, et al., The transcription factor Sry-related HMG box-4 (SOX4) is required for normal renal development in vivo, Developmental dynamics : an official publication of the American Association of Anatomists, 2013, 242(6), 790-9.

79. Kobayashi, A, Valerius, M.T, Mugford, J.W, Carroll, T.J, Self M, Oliver, G, McMahon, A.P, Six 2 defines and regulates a multipotent self-renewing nephron progenitor population throughout mammalian kidney development, Cell stem cell, 2008, 3(2), 16981 .
80. Davies, J.A, Morphogenesis of the metanephric kidney, The Scientific World Journal, 2002, 2, 1937-50.

81. Goto, S, Yaoita, E, Matsunami, H, Kondo, D, Yamamoto, T, Kawasaki, K, Arakawa, M, Kihara, I, Involvement of R-cadherin in the early stage of glomerulogenesis, Journal of the American Society of Nephrology : JASN, 1998, 9(7), 1234-41.

82. Petermann, A, Hiromura, K, Pippin, J, Blonski, M, Couser, W.G, Kopp, J, Mundel, P, Shankland, S.J, Differential expression of dtype cyclins in podocytes in vitro and in vivo, The American journal of pathology, 2004, 164(4), 1417-24.

83. Gomez, R.A, Belyea, B, Medrano, S, Pentz, E.S, Sequeira-Lopez, M.L, Fate and plasticity of renin precursors in development and disease, Pediatric nephrology (Berlin, Germany), 2014, 29(4), 721-6.

84. Lin, E.E, Sequeira-Lopez, M.L, Gomez, R.A, RBP-J in FOXD1+ renal stromal progenitors is crucial for the proper development and assembly of the kidney vasculature and glomerular mesangial cells, American journal of physiology, Renal physiology, 2014, 306(2), F249-58.

85. Sequeira Lopez, M.L, Gomez, R.A, Development of the renal arterioles, Journal of the American Society of Nephrology : JASN, 2011, 22(12), 2156-65.

86. Sequeira-Lopez, M.L, Nagalakshmi, V.K, Li, M, Sigmund, C.D Gomez, R.A, Vascular versus tubular renin: role in kidney development, American journal of physiology. Regulatory, integrative and comparative physiology, 2015, 309(6), R650-7.

87. Sequeira Lopez, M.L, Pentz, E.S, Robert, B, Abrahamson, D.R, Gomez, R.A, Embryonic origin and lineage of juxtaglomerular cells, American journal of physiology. Renal physiology, 2001, 281(2), F345-56.

88. Gomez, R.A, Lopez, M.L, Plasticity of Renin Cells in the Kidney Vasculature, Current hypertension reports, 2017, 19(2), 14.

89. Lichtnekert, J., Kaverina, N.V, Eng, D.G, Gross, K.W, Kutz J.N, Pippin, J.W, Shankland, S.J, Renin-Angiotensin-Aldosterone System Inhibition Increases Podocyte Derivation from Cells of Renin Lineage, Journal of the American Society of Nephrology : JASN, 2016, 27(12), 3611-3627.

90. McClelland, A.D, Lichtnekert, J, Eng, D.G, Pippin, J.W, Gross K.W, Gharib, S.A, et al., Charting the transcriptional landscape of cells of renin lineage following podocyte depletion, PLoS One, 2017, 12(12), e0189084.

91. Pan, L, Gross, K.W, Transcriptional regulation of renin: an update, Hypertension, 2005, 45(1), 3-8.

92. Steppan, D, Zugner, A, Rachel, R, Kurtz, A, Structural analysis suggests that renin is released by compound exocytosis, Kidney international, 2013, 83(2), 233-41.

93. Pratt, R.E, Carleton, J.E, Richie, J.P, Heusser, C, Dzau, V.J, Human renin biosynthesis and secretion in normal and ischemic kidneys, Proceedings of the National Academy of Sciences of the United States of America, 1987, 84(22), 7837-40.

94. Izawa, I, Goto, H, Kasahara, K, Inagaki, M, Current topics of functional links between primary cilia and cell cycle, Cilia, 2015, 4,12 .

95. Maharjan, Y, Lee, J.N, Kwak, S, Lim, H, Dutta, R.K, Liu, Z.Q, et al., Autophagy alteration prevents primary cilium disassembly in RPE1 cells, Biochemical and biophysical research communications, 2018, 500(2), 242-248.

96. Marra, A.N, Li, Y, Wingert, R.A, Antennas of organ morphogenesis: the roles of cilia in vertebrate kidney development, Genesis, 2016, 54(9), 457-69.

97. Deane, J.A, Ricardo, S.D, Emerging roles for renal primary cilia in epithelial repair, International review of cell and molecular biology, 2012, 293,169-93.

98. Han, S.J, Jung, J.K, Im, S.S, Lee, S.R, Jang, B.C, Park, K.M, Kim J.I, Deficiency of primary cilia in kidney epithelial cells induces epithelial to mesenchymal transition, Biochemical and biophysical research communications, 2018, 496(2), 450-454.

99. Jamal, M.H, Nunes, A.C.F, Vaziri, N.D, Ramchandran, R, Bacallao, R.L, Nauli, A.M, et al., Rapamycin treatment correlates changes in primary cilia expression with cell cycle regulation in epithelial cells, Biochemical pharmacology, 2020, 178, 114056.

100. Kobayashi, T, Dynlacht, B.D, Regulating the transition from centriole to basal body, The Journal of cell biology, 2011, 193(3), 435-444.

101. Sanchez, I, Dynlacht, B.D, Cilium assembly and disassembly, Nature Cell Biology, 2016, 18(7), 711-7. 
http://edergi.cbu.edu.tr/ojs/index.php/cbusbed isimli yazarın CBU-SBED başlıklı eseri bu Creative Commons Alıntı-Gayriticari4.0 Uluslararası Lisansı ile lisanslanmıştır.

\section{(c) (1) (9)}

